\title{
Operating Companies as Collaborative Communities for Emergent Innovation
}

\author{
Moses Yonggwan Park \\ Faculty of Business Management, Osaka Sangyo University, Japan
}

Copyright $\subset 2016$ by authors, all rights reserved. Authors agree that this article remains permanently open access under the terms of the Creative Commons Attribution License 4.0 International License

\begin{abstract}
Drawing upon an analytical framework, interviews, and a questionnaire survey, this study explores the reasons for necessity to operate companies as collaborative communities for implementing emergent innovation and the ways in which associate-centered leadership facilitates emergent innovation and helps organizations respond to turbulent conditions. Associate-centered leadership is the method, process, or capacity of influencing associates to achieve the group mission and vision by providing a context in which all associates can demonstrate their abilities. Unlike the prevailing leader-centered power model, associate-centered leaders encourage associates to question premises grounded in old experiences, assumptions, and beliefs. Leaders in an associate-centered model create visions and wisdom, serve, facilitate, moderate, make peace, and express thanks.
\end{abstract}

Keywords Collaborative Community, Associate-centered Leadership, Emergent Innovation

\section{Background/ Objectives and Goals}

In today's global business, organizations confront dynamic and unstable conditions characterized by shortened lifecycles for technology and products and dominant competitors who may exit markets abruptly. Merely improving productivity and practices is insufficient in such an environment. Emergent innovation is needed to master the situation. In order to survive and grow, organizations need systematic abilities to innovate and deliver technologies, products, and services. Doing so demands leadership outside conventional models, as Gratton reported from the New Models of Leadership conference at the 2011 World Economic Forum: "There was broad agreement that the hierarchical command-and-control leadership style of the past could not help hold up for the future. In its place would come a more transparent, authentic, and peer-based way of leading". 1(p159-61) In today's global business environment, leaders must nurture and support associates so that each can promote emergent innovation.

Leader-centered management emphasizing command and control is particularly ineffective in nurturing emergent innovation. Instead, leaders must avoid arrogance that may accompany their position in the organization and controlling employees through domination.

This study explores the reason for the necessity to operate companies as collaborative communities for implementing emergent innovation and the ways in which associate-centered leadership enables emergent innovation and helps organizations respond to turbulent conditions. Associate-centered leadership is the method, process, or capacity of influencing associates to achieve the group mission and vision by providing a context in which all associates can demonstrate their abilities. Associate-centered leaders encourage, assist, serve, facilitate, moderate, and appreciate associates. Associate-centered leadership encourages associates to question premises grounded in old experiences, assumptions, and beliefs.

\section{Methods}

Drawing upon an analytical framework from earlier literature, this study explores the reasons for the necessity to operate companies as collaborative communities for implementing emergent innovation and the study also shows associate-centered leadership enables emergent innovation and helps organizations respond to turbulent conditions. This study presents findings from five years of interviews with the CEO of Greenleaf Center for Servant Leadership and managers at Buckman Laboratories, W. L. Gore \& Associates, Ford Motor Company, POSCO, Samsung Electronics, and BenQ (2009) as well as interviews with managers from Google, IDEO, Southwest Airlines, Whole Foods Market, 3M (2010) and Nordstrom (2011). The study concludes with the results of a questionnaire survey on effective organizations that was conducted with the CEO of the Greenleaf Center for Servant Leadership and with managers of Hyundai Mobis in North America (2011) and Whole Foods Market (2014). 


\section{Results}

\subsection{Emergent Innovation in Turbulent Times}

This study categorizes innovation as incremental and emergent. Incremental innovation denotes continuous improvement in existing technologies, products, services, and processes without significant changes or major investment. Undertaken in accord with "common sense" and routine, it does not synergize efforts.

Emergent innovation-also called discontinuous innovation, rupture innovation, radical innovation, disruptive innovation, or invented innovation-is generated by thinking beyond the present conditions and established cognitive/behavioral premises. It requires a continual questioning of "common sense." It results in products, services, or business models delivered in novel ways. It requires organizations open to questioning assumptions and debating alternatives. ${ }^{2\left(\mathrm{p}^{23)}\right)}$ Morris $^{3(\mathrm{pp} 87,152)}$ substantiates the importance of questions as tools for exploring and generating emergent innovation.

Organizations content with incremental innovation become uncompetitive during unstable and discontinuous change. Sony Corporation illustrates this idea. Sony has persisted with incremental innovation and has prospered since introducing the Walkman in 1979. However, Sony now faces intense competition from iPod-maker Apple Inc., and its brand is being devalued by Samsung Electronics. Incremental innovation is insufficient; emergent innovation is required to survive and grow in turbulent times.

An example of emergent innovation is ticketless service in the airline industry. Southwest Airlines sought to increase customer satisfaction by alleviating the tedium of standing in check-in lines. Had the company followed "common sense," it would have considered providing better service at the counter. Instead, Southwest asked why tickets were even necessary and introduced ticketless service in 1994. The company reduced waiting time, simplified check-in, and reduced costs. ${ }^{4(\mathrm{p} 135-39) ;}$ Interview with Elizabeth Bryant on March 24, 2010

\subsection{Necessity for Operating Companies as Collaborative Communities for Implementing Emergent Innovation}

An organization needs people to create knowledge. Therefore, it is important that leaders provide contexts in which associates create and accumulate knowledge. ${ }^{5(\mathrm{pp} 49-59}$, 72-4, 124, 239-40) Numerous questions emerge: How do leaders awaken associates' spontaneity, creativity, and passion? How can leaders garner participation in innovation and increase creativity? How can leaders build organizations that facilitate emergent innovation? This study addresses these questions by delineating operating company as collaborative communities and associate-centered leadership.

The industrial society dominated by incremental innovation has transformed into a post-industrial, information-based, and knowledge-based global society of change and uncertainty. Organizations need new ways to encourage emergent innovation. Continuous improvement and quality control increase productivity, but not necessarily emergent innovation. Traditional systems, practices, and customs are also unlikely to produce creativity or lead to emergent innovation.

These changes necessitate the operation of companies as collaborative communities. Industrial-age definitions as "a system of consciously coordinated activities or force of two or more persons for at least one definite end" ${ }^{1(665-81)}$ may suffice for effecting incremental innovation, but not emergent innovation. Emergent innovation requires organizations to be collaborative communities, not cooperative systems.

Communities outperform bureaucracies. As Judge et al. note, "highly innovative units behaved as focused communities, while less innovative units behaved more like traditional bureaucratic departments". ${ }^{7(p 74-6)}$ Hierarchies aggregate effort but are poor at mobilizing human capabilities, creating ideas, and inspiring associates to go beyond. ${ }^{8(\mathrm{p} 61-5)}$ Workplace communities rely not on control but on empowering workers toward their best within shared objectives. ${ }^{7(\mathrm{p} 81-3)}$

Mintzberg calls enterprises "a community of engaged members, not a collection of free agents" ${ }^{\text {"(p25) }}$ and espouses community: "Companies must remake themselves into places of engagement, where people are committed to one another and their enterprise." ${ }^{10(\mathrm{p} 140)}$ Gratton also describes the corporations are "fundamentally collections, teams, and communities of people". (pviii) Hill et al. argue that community drives associates' willingness to do innovation, and the role of leader is not to be the source of innovation but to create a context where associates' individual slices of genius could emerge. ${ }^{11(p 68-93)}$ Hamel describes Whole Foods as a community working together to create value for the people, shared sense of purpose, shared fate, and shared mission. ${ }^{8(\mathrm{p} 69-82)}$ Drucker $^{12}$ notes that each organization has a mission.

I view an organization as a community with a mission, and each element has its own mission. If leaders uphold the vision, collaborators with whom the vision resonates become participants of that community. Such an organization becomes a collaborative community of two or more associates who achieve a vision. Within the collaborative community, people are partners who embrace the vision and become its subject in achieving the mission. Collaborative communities are warm, visionary systems with a mission. The community itself becomes the autonomous, open, and generous collaboration it engenders. The organization as collaborative community has leaders, not bosses, and associates or partners, not subordinates. Roles differ, but visions and missions are shared; there are not directors or managers, but co-visionaries or commissioners.

Examples of for-profit collaborative communities include W. L. Gore \& Associates, Semco, Whole Foods Market, and Orpheus Chamber Orchestra. ${ }^{13}$ Churches can be 
collaborative communities. The film The Help ${ }^{14}$ exemplifies a successful non-profit organization. It concerns a young white woman who collaborates with black maids to write a book from their viewpoints, exposing the racism they face working for white families.

\subsection{Seven Roles of Associate-centered Leaders to Enable Emergent Innovation}

These ideas about organization as collaborative communities transform our understanding of leaders' roles. This study argues that leaders in an associate-centered model observe the seven roles of leaders: they create a vision, foster wisdom, serve, facilitate, moderate, keep organizational peace, and express thanks.

First, it is of paramount importance that leaders have a vision and passion for implementing emergent innovation. Leaders point their organizations in appropriate directions. Although a leader attracts and motivates people with a sense of fulfillment and organizational belonging as well as a feeling of qualification, self-esteem, and reward, associates must be energized to pursue the vision. Associates aligned with the organization's vision commit to realizing this vision or direction. ${ }^{15(\mathrm{p} 175-7)}$

People often confine themselves to old ideas, traditions, customs, and cultures, and leaders often cling to past successes. Relying on previous successes may impede emergent innovation and even foster failure. Leaders need to set aside successful experiences and let associates suggest new ideas that address challenges.

Whole Foods Market is a vision-driven company. It believes that companies must assume responsibility for Planet Earth. Led by this vision, Whole Foods supports organic farming to promote sustainable agriculture and protect farm workers and the environment. The company supports alternative energies, recycling, and composting. Whole Foods is active in its communities by supporting food banks, sponsoring neighborhood events, and contributing at least $5 \%$ of its profits to not-for-profit organizations. The company's vision-"Whole Foods-Whole People-Whole

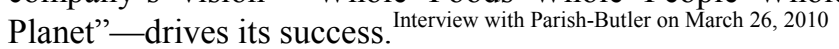

Second, emergent innovation requires leaders to do more than direct and control subordinates through data-based plans and programs. They guide associates through insights from understanding situations, recognizing priorities, and showing the right direction. They should try to acquire the wisdom to overcome obstacles, not avoid them. ${ }^{15(\mathrm{p} 175)}$

Leaders should also support associates, encourage ideas, question assumptions, and debate alternatives that arise in managing a business. Ideas include providing suggestions for new services or products, revising business processes, acquiring technologies, or adopting new business models. The role of leaders is "to create an environment to nurture the generation of large quantities of great ideas."2(p127)

The film Fly Away Home, ${ }^{16}$ directed by Carroll Ballard, provides insights into leadership through wisdom. As Amy rides on a lawn tractor, leading a parade of geese, her father watches, knowing that migration season approaches. To migrate, geese must fly. In her role as Mother Goose, Amy can teach them to run but not to fly. Amy's father begins to research homemade aircraft as a way to teach the geese to fly. He learns that if the birds are not taught to fly properly, they will fly off on their own, and possibly get lost and perish in winter. Amy's father manufactures a goose-shaped airplane for Amy to lead the geese from Canada to North Carolina. ${ }^{17(\mathrm{p} 12-3)}$

Third, to achieve emergent innovation, it is imperative that leaders support and serve associates by providing them with opportunities to extend boundaries and develop specializations whereby they can contribute creatively and independently. Although managers generally support empowerment in the abstract, many mistake empowering employees for reducing their authority. While proclaiming empowerment, they still "interfere." Empowerment means trusting employees, for trust is the most important form of encouragement. Even when problems arise, a leader must believe in and support associates so they can cultivate their talents. Leaders must use their experience to support and serve their organizations' members so that they can implement emergent innovation to overcome crises. ${ }^{15(\mathrm{p} 174-5)}$

Nordstrom believes employees are entrepreneurs who can judge the best course of action and trusts them to make decisions. For example, any employee may receive returned goods without interrogating the customer and without a manager's approval. If customers want something Nordstrom does not have, employees issue a special order or buy the item from a competitor. Nordstrom reimburses employees who use their own credit cards for this purpose. $^{18(\mathrm{p} 113-40)}$ Nordstrom's Employee Handbook stipulates only one rule: "Use good judgment in all situations". ${ }^{18(\mathrm{p} 7)}$

Bayside Shakedown 2 is a Japanese film that demonstrates the leader-as-server. It depicts an authoritarian chief of police who treats subordinates as objects and does not communicate with investigators. The chief is replaced after an investigator is shot, and the new chief empowers investigators in ways the predecessor did not: "Don't wait for commands from headquarters! Do as you think best! I believe in your judgment on the spot!"19

Fourth, to promote emergent innovation, leaders must facilitate associates' talents, creativity, and independence in an open system wherein everyone addresses challenges and takes initiative. Leaders must be facilitators who trust and believe in associates. Another role of a leader is finding a successor. Effective leaders facilitate associates to mature into leaders. ${ }^{15(\mathrm{p} 177)}$

The leaders of Whole Foods facilitate growth among all associates. At Whole Foods, leaders empower all associates seek the finest natural and organic foods, maintain strict quality standards, and are ably committed to sustainable agriculture. Associates make independent decisions and create a respectful workplace where people are treated fairly and motivated to succeed. The organization's philosophy is to delight customers and to support employee wellbeing and 
excellence because its leaders view all associates as valued contributors. Interview with Parish-Butler on March 26, 2010, and May 2, 2014

Fly Away Home also provides insights into leaders as facilitators. Amy becomes impatient because Igor, the weakest and slowest of the gaggle, cannot fly with her. Amy encourages the goose through a wireless apparatus in her aircraft: "Igor, we need to leave by the end of this weekend. Come on! You can do it, Igor. Come on!" In this poignant scene, Igor finally flies alongside Amy. When Amy and her father make their last flight for North Carolina, her father's aircraft crashes. He is injured and he cannot continue the flight. He encourages Amy, on the verge of tears, to lead the geese to their winter destination. Her father says there is not enough fuel for both of them. If they fly together, they would not arrive on time. He convinces her to complete the trip by telling her, "You look like your mother who was brave, strong, and stood up to challenges." Thomas is a facilitator who motivates a thirteen-year old to lead. ${ }^{17(\mathrm{p} 14-6)}$

Fifth, leaders must be of moderate disposition and allow for associates' failures and faults to implement emergent innovation. ${ }^{20}$ Leaders must encourage associates to innovate. Irrespective of success or failure, they must praise associates for having ideas and addressing challenges.

Tolerating failure is a paradox common to successful associate-centered innovation. Achieving breakthroughs in the long term may mean accepting short-term failures. The objective is to learn from mistakes, not punish them. ${ }^{21}$; 2(pp211,228) Punishing failure may stifle emergent innovation. ${ }^{2(\mathrm{pp} 27,131-2,207-8)}$ Leaders create organizational cultures that inspire associates to keep innovating and challenging problems while disregarding failure. ${ }^{3(\mathrm{p} 176)}$

IDEO, 3M, and Amazon support associates through policies and practices that acknowledge the risk of failure. Through failures as well as successes, associates learn to share the best practices.

IDEO provides associates considerable latitude. To help others, associates must not be overloaded with their own tasks. Interview with Tom Kelley on February 15, 2010 Availability of potential helpers allows associates to engage each other in unplanned ways.

$3 \mathrm{M}$ observes an unwritten rule that employees devote $15 \%$ of their working hours to their favorite research. They can create, explore, take risks, succeed, and fail without penalty, because failures become successes when they meet

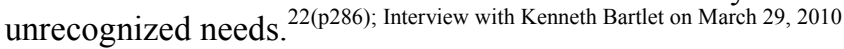

Another example of learning from failure is Amazon's "Just do it" Award, presented to associates who tried something that, although well thought-out, did not succeed. Recognition for trying something new is important there. ${ }^{23}$

In response to my questionnaire, Parish-Butler from Whole Foods noted:

Radical empowerment granted to even the most entry-level positions can create a sense of ownership that is highly valuable for innovation. At Whole Foods Market, all ideas are welcome, and all team members are encouraged to try new ideas. Many initiatives that have spread across the company began as ideas of front line teams. ${ }^{\text {questionnaire response }}$ on May 2, 2014

Although leaders as moderators accept associates' failures with open minds, they do not tolerate failure to address challenges. At W. L. Gore Associates, employees adhere to the principle of freedom, one of four guiding principles articulated by Bill Gore. Although freedom to address challenges and to fail is included, freedom to avoid challenges is not. $^{22(\mathrm{p} 85)}$

Sixth, for emergent innovation to occur, leaders must foster relations with associates and unite them because anger, conflicts, and confrontations deter innovation. They ought to prepare for conflicts, diagnose their causes, and resolve them by maintaining balance throughout the organization, being fair to intermediaries, and obtaining consensus. ${ }^{15(\mathrm{p} 173-4)}$

According to Blush, masters of organizational behavior recognize problems, diagnose conflicts, and resolve them. ${ }^{24(\mathrm{p} 154)}$ Blackaby argued that healthy organizations encourage a diversity of personalities, but organizational vitality wanes amid an atmosphere of constant discord. Therefore, leaders must encourage vigorous debate and energetic dialogue among associates but not allow animosity to fester within the organization. ${ }^{25(340-1)}$

Fly Away Home offers insights into the leader as a peacemaker. When Amy's father takes Amy to her old room after an automobile accident, he apologizes for the mess created in her absence. Amy's father and Susan return home late one night and find Amy asleep in her father's workshop with the 16 hatched goslings. He covers her with his coat and lets her keep the birds. That action marked the onset of resolving conflicts among Amy, Susan, and her father. Thomas leads as a peacemaker by explaining to Amy what happened between him and her mother; he admits his mistakes and empathizes with her. In another scene, Amy's father, as peacemaker, helps Amy and Susan resolve their conflicts. He comforts, encourages, and loves Amy and acknowledges he hurt her, apologizes, and asks her forgiveness. Later, Susan acts as peacemaker between Amy and her father. ${ }^{17(\mathrm{p} 8-9)}$

Seventh, to achieve emergent innovation leaders must cultivate intrinsic motivation by recognizing, praising, and appreciating associates. External rewards may reduce performance by stifling intrinsic motivation and the curiosity that drives associates to innovate. ${ }^{2(\mathrm{p} 205) ; 26(\mathrm{pp} 34-59,210)}$ Intrinsic innovation arises from feelings of accomplishment-for example, through finding meaning in work, recognition from peers and superiors, or satisfaction from seeing the results of their efforts.

Expressions of appreciation, praise, and gratitude that show concern, respect, and trust sustain associates on a path toward useful innovation, particularly emergent innovation. Jim Collins noted that Level-5 leaders are quick to praise others and acknowledge the contributions of their team. Marshall Goldsmith stressed the importance of leaders thanking associates for their work. ${ }^{27(\mathrm{pp} 49,162-9)}$ Branchard emphasized that praise is the most powerful activity a leader can engage in as it reinforces behavior that moves people toward goals and drives associates to innovate. ${ }^{28(\mathrm{p} 136-7)}$ 
Fly Away Home also offers insights into the leader as thanks-giver. When Amy lands with her geese amid a cheering crowd, Susan and her father hug, and he thanks her. Amy throws her arms around his neck and thanks him. The crowd celebrates and thanks them. For that matter, the geese rejoice and splash about on the lake. These scenes leave deep impressions about giving and receiving thanks. ${ }^{17(\mathrm{p} 16)}$

\subsection{Implications}

This study makes several theoretical contributions to organizational theory and leadership. First, it shows why companies need to function as collaborative communities in order to implement emergent innovation. Organizations need to create knowledge, and leaders must provide contexts in which all associates create and accumulate knowledge during unstable and discontinuous times.

Second, this study argues that associate-centered leadership facilitates emergent innovation and helps organizations respond to turbulent conditions. Emergent innovation requires leaders to go above and beyond directing and controlling subordinates. They must create a vision; foster wisdom; keep organizational peace; and encourage, assist, serve, facilitate, moderate, and appreciate associates.

Third, we show that managers with a single-minded focus on a purpose are not essential for emergent innovation, whereas leaders who awaken associates' spontaneity, creativity, and passion are indispensable.

This study also provides practical insights into emergent innovation and effective organizations and explains why emergent innovation and associate-centered leadership are of paramount important for addressing challenges. Incremental innovation is insufficient. Emergent innovation is required to survive and grow in a global business environment. The study recommends that companies evolve from cooperative systems to collaborative communities outside traditional systems, practices, and customs that were successful in an industrial society.

These apply not only to formal, profit-driven organizations but also to informal, not-for-profit organizations.

\section{REFERENCES}

[1] Gratton L. The Key: How Corporations Succeed by Solving the World's Toughest Problems, New York: McGraw Hill Education; 2014. 272p.

[2] Davila T, Epstein MJ, Sheton RD. Making Innovation Work: How to Manage It, Measure It, and Profit from It (Rev. Ed.), New Jersey: FT Press; 2013. 368p.

[3] Morris L. Permanent Innovation: The Definitive Guide to the Principles, Strategies, and Methods of Successful Innovators. CA: Innovation Academy; 2006. 255p.

[4] Freiberg K, Freiberg J. Nuts!: Southwest Airlines' Crazy
Recipe for Business and Personal Success. New York: Broadway Books; 1996. 362p.

[5] Nonaka I, Takeuchi H. The Knowledge-Creating Company: How Japanese Companies Create the Dynamics of Innovation. New York: Oxford University Press; 1995. 304p.

[6] Barnard CI. The Functions of the Executive. Cambridge: Harvard University Press; 1938. 384p.

[7] Judge WQ, Fryxell GE, Dooley RS. The New Task of R\&D Management: Creating Goal-Directed Communities for Innovation. California Management Review. 1997 Spr;39(3): $72-85$.

[8] Hamel G, Breen B. The Future of Management. Massachusetts: Harvard Business School Press; 2007. 288p.

[9] Mintzberg H. Productivity is Killing American Enterprise. Harvard Business Review. 2007 Jul/Aug; 85(7/8):25.

[10] Mintzberg H. Rebuilding Companies as Communities. Harvard Business Review 2009 Jul/Aug; 87(7/8):140-143.

[11] Hill LA, Brandeu G, Truelove E, Lineback K. Collective Genius: The Art and Practice of Leading Innovation. Boston: Harvard Business Review Press; 2014. 320p.

[12] Drucker PF. Concept of the Corporation. New Jersey: Transaction Publishers; 1993. 329p.

[13] Seifter H, Economy P. Leadership Ensemble: Lessons in Collaborative Management from the World's Only Conductorless Orchestra. New York: Times Books; 2001. $256 \mathrm{p}$.

[14] Taylor T. (Writer/Director). The Help [Motion Picture]. 2011.

[15] Park YM. New Leadership for Enabling Emergent Innovation. The Annual of the Society of Economic Sociology 2013 Sept; 35: 171-184.

[16] Ballard C. (Director). Fly Away Home written by Lishman B, Rodat R, McKewin V. [Motion Picture]. 1997.

[17] Kim SS, Park YM. A Study on Servant Leadership: With Special Reference to the Film Fly Away Home. Osaka Sangyo University, Journal of Business Administration 2014 Jun; 15(2/3): 1-16.

[18] Spector R, McCarthy PD. The Nordstrom Way: The inside Story of America's \#1 Customer Service Company. New Jersey: John Wiley \& Sons Inc; 2005. 256p.

[19] Motohiro K (Director) Bayside Shakedown 2: Save the Rainbow Bridge [Motion Picture]. 2003.

[20] Park YM. Effective Organization for Enabling Emergent Innovation in Changing Times. Proceedings of the 12th World Congress of IFSAM 2nd-4th 2014 Sep; T15 Park M 113 .

[21] Amabile TM. How to kill creativity. Harvard Business Review 1998 Sep-Oct; 76(5): 76-87.

[22] Park YM. Network Organization Theory. Kyoto: Minerva Publishing Co., Ltd; 2003. (Japanese.)

[23] Timberg C. Yang J L. Bezos J, The Post's incoming owner, known for a demanding management style at Amazon. The Washington Post [Internet] 2013 Aug 8. [cited 2014 Jun 4]. Available from: http:/www.stumbleupon.com/su/ 4mcrRq 
[24] Brush K. Leadership = Motivation = Innovation + Productivity: Get Ready for the Latest Global Challenges, Lexington: Kathleen Brush; 2011. 252p.

[25] Blackaby HT, Blackaby R. Spiritual Leadership (Revised \& Extended), Nashville: B\&H Books; 2011. 418p.

[26] Pink DH. Drive: The Surprising Truth about What Motivates
Us. New York: Canongate; 2009. 256p.

[27] Crainer S, Dearlove D. Leadership: Organizational Success Through Leadership. New York: McGraw Hill Education; 2014. 192p.

[28] Blanchard K. Leading at a Higher Level (Revised and Expanded Edition). New Jersey: FT Press; 2010. 362p. 